\title{
Profil Spasial Batimetri, Salinitas, Suhu, dan Densitas di Perairan Teluk Tambelan, Kepulauan Riau
}

Yuliantia $^{*}$, Desti Ardiania, Fratiwi Susantia, Muliadia, Arie Antasari Kushadiwijayanto ${ }^{b}$

\author{
aProgram Studi Fisika, FMIPA Universitas Tanjungpura, \\ bProgram Studi Ilmu Kelautan, FMIPA Universitas Tanjungpura, \\ Jalan Prof. Dr. Hadari Nawawi, Pontianak, Indonesia \\ *Email : yuliantiyul79@gmail.com
}

\begin{abstract}
Abstrak
$\overline{\text { Penelitian profil batimetri, salinitas, suhu, dan densitas telah dilakukan di Perairan Teluk Tambelan, }}$ Provinsi Kepulauan Riau. Tujuan dari penelitian ini adalah melakukan pemetaan terhadap kondisi kedalaman, salinitas, suhu, dan densitas di perairan tersebut. Pengukuran batimetri, salinitas, dan suhu dilakukan secara langsung menggunakan metode random sampling. Hasil dari penelitian digambarkan dalam bentuk peta kontur kedalaman ISLW (Indian Spring Low Water) berkisar antara 0,2 - 24,3 meter dengan nilai rata-rata 8,1 meter. Salinitas di kedalaman 0,2d berkisar antara $30-35 \%$ dengan nilai ratarata 34,5 \%o dan di kedalaman 0,8d salinitas berkisar antara 30 - $35 \%$ dengan rata-rata 34,42\%o. Suhu di lapisan $0,2 d$ berkisar antara $28,5-31{ }^{\circ} \mathrm{C}$ dengan nilai rata-rata $30{ }^{\circ} \mathrm{C}$ dan suhu di lapisan $0,8 d$ berkisar antara $28-31{ }^{\circ} \mathrm{C}$ dengan rata-rata $29,5^{\circ} \mathrm{C}$. Densitas kedalaman $0,2 d$ berkisar antara $1019 \mathrm{Kg} / \mathrm{m}^{3}-1021,5$ $\mathrm{Kg} / \mathrm{m}^{3}$ dengan nilai rata-rata 1020,64 Kg/m³ , sedangkan densitas kedalaman 0,8d berkisar antara 1019 $\mathrm{Kg} / \mathrm{m}^{3}-1021,5 \mathrm{Kg} / \mathrm{m}^{3}$ dengan rata-rata $1021,05 \mathrm{Kg} / \mathrm{m}^{3}$.
\end{abstract}

Kata Kunci :Teluk Tambelan, Batimetri, Salinitas, Suhu, Densitas, ISLW

\section{Latar Belakang}

Teluk Tambelan merupakan salah satu teluk terbesar yang berada di Pulau Tambelan Besar dan menjadi pusat pertumbuhan dan kegiatan ekonomi di Kecamatan Tambelan, Provinsi Kepulauan Riau [1]. Wilayah teluk memiliki peran penting dalam kegiatan navigasi, pelabuhan, dan perekonomian bagi masyarakat seperti budidaya ikan. Sebagai teluk terbesar, teluk ini juga mendapat masukan air tawar berasal dari perbukitan yang berada di sekitar teluk, sehingga menyebabkan beberapa bagian teluk memiliki salinitas rendah yang dapat terindikasi dari jenis tumbuhan mangrove yang tumbuh di lokasi tersebut. Ada beberapa spesies mangrove yang tumbuh di teluk ini yaitu Rhizophora, seperti $R$. Stylosa, R. Mucronata, dan R. Apiculata. Selain memiliki peran ekonomis dan ekologis, teluk ini juga merupakan lokasi coremap, yang memiliki terumbu karang yang menyebar di sekitar teluk dan pulau-pulau di sekitarnya [2].

Daya dukung Teluk Tambelan tidak lepas dari kondisi fisik yang ada di dalam teluk. Kondisi fisik meupakan faktor penting dalam ekosistem suatu teluk karena kondisi fisik merupakan batas bagi biota laut untuk hidup di dalamnya. Syarifudin pada tahun 2010 menjelaskan bahwa pola arus di sekitar Kepulauan Tambelan sangat dipengaruhi oleh musim, pasang surut, dan topografi perairan [3]. Kisaran suhu dan salinitas di perairan sekitar pulau berada masing-masing pada rentang $28,59-32,62{ }^{\circ} \mathrm{C}$, dan $32,01-32,62$. Pada tahun 2017 menyatakan bahwa kisaran gelombang di dalam teluk berada pada rentang 0,07-0,47 m[4].

Penelitian tersebut telah banyak memberi informasi mengenai gambaran umum di sekitar Kepulauan Tambelan namun belum dapat memberikan informasi mengenai kondisi spesifik seperti kedalaman, salinitas, suhu, dan densitas. Penelitian ini bertujuan untuk memberi gambaran mengenai batimetri, salinitas, suhu, dan densitas di Teluk Tambelan. Hasil penelitian ini diharapkan dapat bermanfaat dalam pengembangan dan pembangunan di Teluk Tambelan.

\section{Metodelogi}

\subsection{Teknik Pengukuran}

Pengukuran dibagi menjadi dua tahap yaitu pengukuran kedalaman (batimetri), salinitas, dan suhu yang dilakukan pada tanggal 26 November 2017 dan pengukuran pasang surut dilakukan pada tanggal 18 November - 18 Desember 2017. Pengukuran kedalaman menggunakan alat Echosounder, dan dipasang di bawah kapal motor dengan jarak 0,5 meter dari permukaan air. Pengambilan data kedalaman dilakukan pada 80 titik sampel yang ditunjukkan pada Gambar 1 . Koordinat di setiap titik lokasi pengukuran diukur menggunakan GPS FURUNO.

Pengambilan sampel air untuk pengukuran salinitas dan suhu pada setiap kedalaman dilakukan menggunakan botol nansen atau botol sampel. Sampling dilakukan pada beberapa kedalaman perairan yaitu dikedalaman $0,2 d$ yang mewakili lapisan permukaan pada setiap titik dan kedalaman 0,8d yang mewakili lapisan dasar 


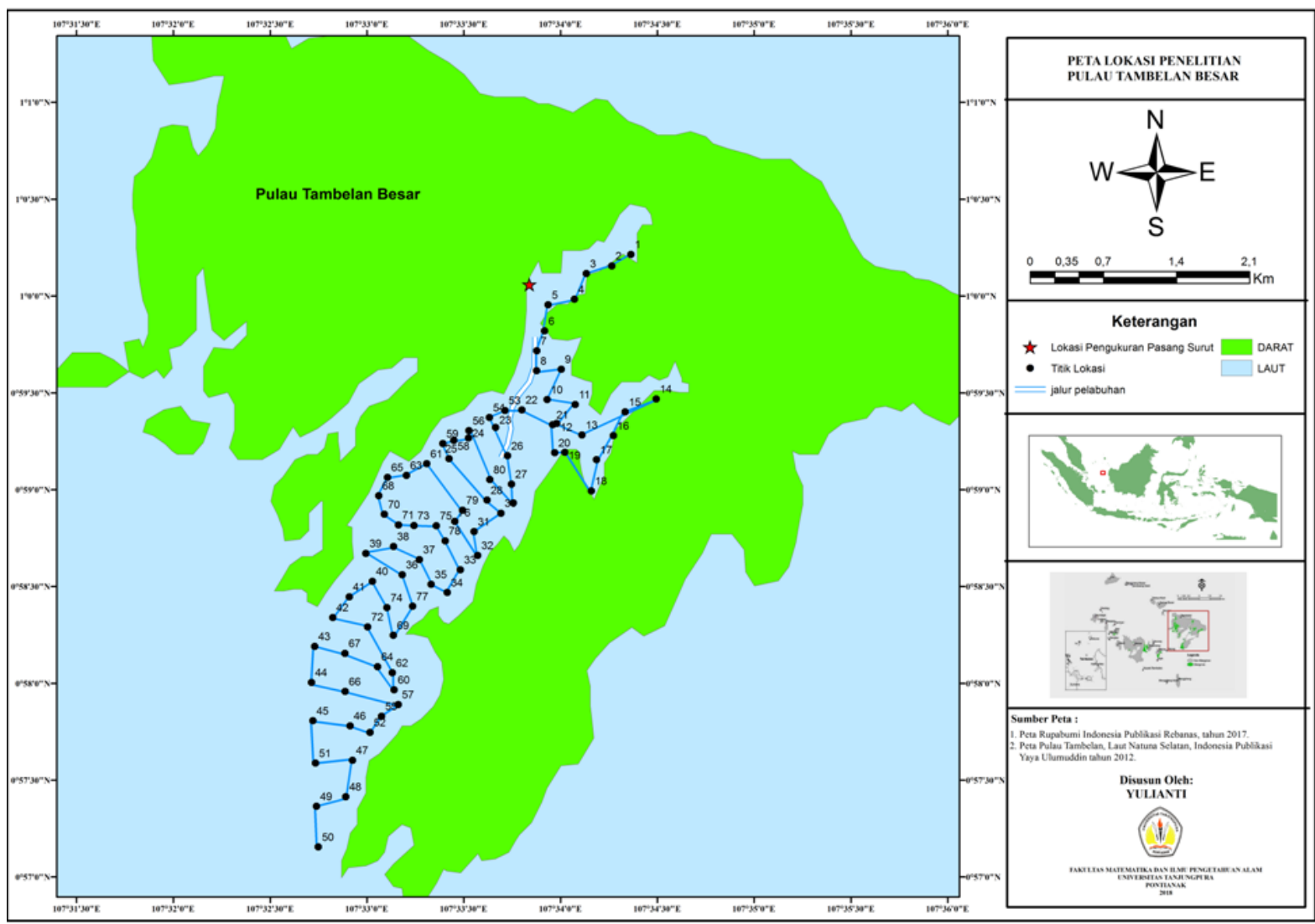

Gambar 1. Lokasi Teluk Tambelan yang menjadi daerah penelitian dengan 80 titik pengukuran kedalaman, salinitas, dan suhu.

perairan. Suhu air laut yang telah diambil diukur menggunakan termometer yang ada di dalam botol nansen. Salinitas diukur menggunakan refractometer.

Pasang surut diukur menggunakan tiang ukur dan lokasi pengukuran berada di bagian kepala teluk, tanda bintang di Gambar 1 . Pencatatan data pasang surut dilakukan secara langsung dengan interval pengukuran 1 jam selama 30. Waktu pengambilan data menggunakan waktu standar Greenwich Mean Time (GMT).

\subsection{Pengolahan data}

Data pasang surut diolah menggunakan t_tide untuk mendapatkan nilai amplitudo dan fase dari masing-masing komponen pasang surut dan MSL. Nilai-nilai tersebut digunakan untuk menentukan nilai chart datum yang digunakan sebagai koreksi data kedalaman. Persamaan perhitungan chart datum menggunakan standar Indian Low Spring Water adalah sebagai berikut [4].

$Z_{0}=S_{0}\left(K_{1}+O_{1}+M_{2}+S_{2}\right)$

dimana,

$\mathrm{Z}_{0} \quad=$ Chart datum
$\mathrm{S}_{0} \quad=$ Mean Sea Level (MSL)

$\mathrm{K}_{1} \quad=$ Konstanta harmonik bersifat harian tunggal, disebabkan oleh gaya tarik bulan dan matahari

$\mathrm{O}_{1}=$ Konstanta harmonik harian tunggal dari bulan

$\mathrm{M}_{2} \quad$ = Konstanta harmonik harian ganda oleh bulan

$\mathrm{S}_{2}=$ Konstanta harmonik harian ganda oleh matahari

Selain penentuan chart datum, kedalaman juga dikoreksi terhadap pasang surut menggunakan persamaan sebagai berikut:

$r T=\left(T W L t-\left(S_{0}+Z_{0}\right)\right)$

dimana,

rT = Besarnya koreksi hasil pengukuran kedalaman pada waktu $\mathrm{t}$

TWLt = Kedudukan permukaan laut sebenarnya (True Water Level) pada waktu $\mathrm{t}$

Sedangkan untuk menentukan kedalamannya, yaitu

$D=d T-r T$ 
Dimana,

D = Kedalaman sebenarnya

dT $\quad=$ Kedalaman terkoreksi transducer

QGIS digunakan untuk memvisualisasikan hasil pengukuran kedalaman sehingga menjadi peta kedalam 2 dimensi.

Kelerengan dasar laut diperoleh dengan menghitung kelerengan (slope) menggunakan peta kontur batimetri dari hasil pengolahan data batimetri. Untuk mengetahui tingkat kelerengan, digunakan metode wenworth dengan persamaan sebagai berikut [6].

$S=\frac{(n-1) x I c}{\Delta h} \times 100 \%$

dimana,

$S \quad=$ nilai kemiringan lereng $(\%)$

$n \quad=$ jumlah kontur

Ic $=$ Interval kontur

$\Delta h \quad=$ jarak horizontal

Pembuatan kontur salinitas, dan suhu dilakukan dengan bantuan QGIS dan diinterpolasi menggunakan metode Inverse Distance Weighted (IDW). Hasil pengolahan yang didapat berupa peta peta salinitas, peta suhu, dan kelerengan perairan.

Pengolahan data densitas menggunakan perhitungan algoritma sifat dasar laut sebagai berikut [7].

$$
\begin{aligned}
\rho(S, t, 0)= & \rho_{w}+\left(b_{0}+b_{1} t+b_{2} t^{2}+b_{3} t^{3}+\right. \\
& \left.b_{4} t^{4}\right) S+\left(c_{0}+c_{1} t+c_{2} t^{2}\right) S^{3 / 2}+ \\
& d_{0} S^{2}
\end{aligned}
$$

Dimana $b_{0}=8,24493 \mathrm{E}-1 ; b_{1}=-4,0899 \mathrm{E}-3 ; b_{2}=$ $7,6438 \mathrm{E}-5 ; b_{3}=-8,2467 \mathrm{E}-7 ; b_{4}=5,3875 \mathrm{E}-9 ; c_{0}$ $=-5,72466 \mathrm{E}-3 ; c_{1}=1,0227 \mathrm{E}-4 ; c_{2}=-1,6546 \mathrm{E}-6$; $d_{0}=4,8314 \mathrm{E}-4$

$\rho_{w}=a_{0}+a_{1} t+a_{2} t^{2}+a_{3} t^{3}+a_{4} t^{4}+a_{5} t^{5}$

dimana, $a_{0}=999,842594\left[-28,263737 ; a_{1}=\right.$ $6,793952 \mathrm{E}-2 ; a_{2}=-9,095290 \mathrm{E}-3 ; a_{3}=1,001685$ $\mathrm{E}-4 ; a_{4}=-1,120083 \mathrm{E}-6 ; a_{5}=6,536332 \mathrm{E}-9$

Keterangan :

$\rho(S, T, 0)=$ Pengukuran

$\rho_{w} \quad=$ Densitas

$\mathrm{S} \quad=$ Salinitas

$T \quad=$ Suhu

Setelah itu data diolah menggunakan QGIS untuk mendapatkan peta kontur densitas.
Adapaun diagram alir penelitian dapat dilihat pada Gambar 2.

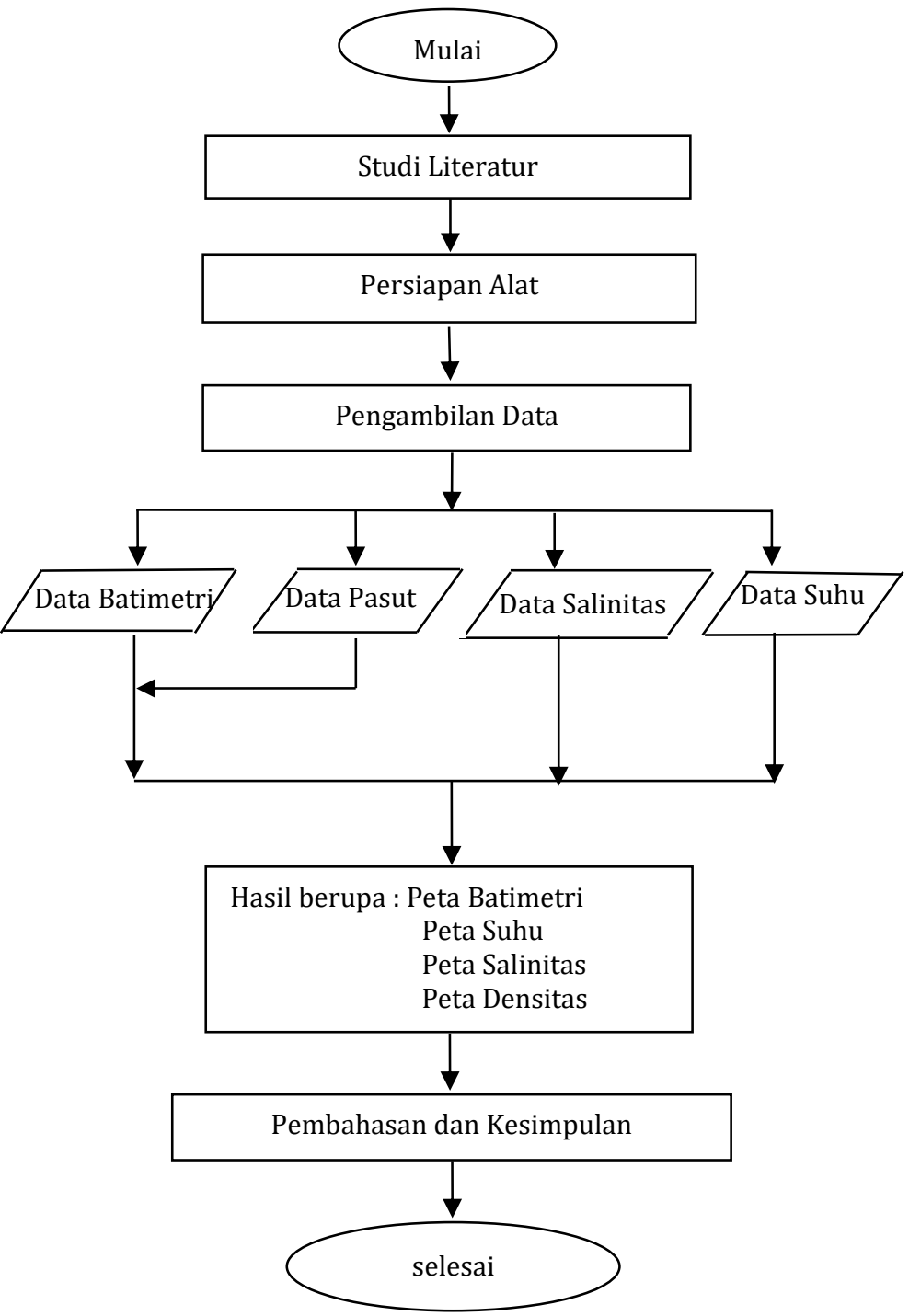

Gambar 2. Diagram Alir Penelitian

\section{Hasil dan Pembahasan}

\subsection{Pasang Surut}

Gambar 3 merupakan grafik pasang surut dengan program t_tide di Perairan Teluk Tambelan. Data pengukuran elevasi muka air per jam selama 30 hari ditunjukkan dengan garis berwarna biru di bandingkan dengan pasang surut astronomis ditunjukkan dengan garis berwarna hijau. Garis berwarna merah merupakan selisih antara pasang surut astronomis dan data pengukuran. Nilai pasang tertinggi sebesar 2,86 meter terjadi pada tanggal 18 Desember. Surut terendah sebesar 1,62 meter terjadi pada tanggal 05 Desember 2017.

\subsection{Diagram Alir Penelitian}




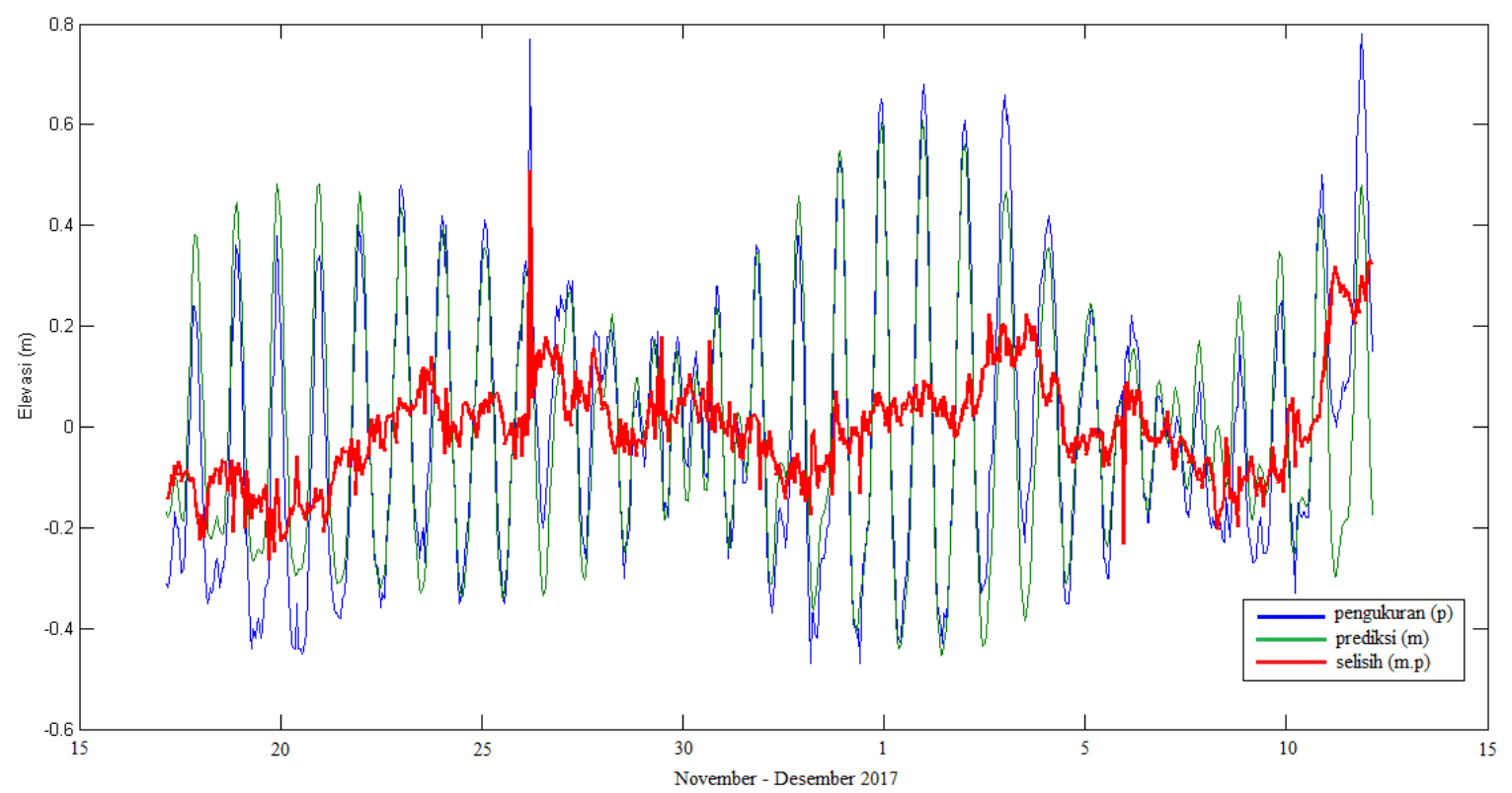

Gambar 3. Grafik Pasang Surut

Tabel 1.Nilai amplitudo dan fase dari 5 konstanta harmonik pasang surut utama di Teluk Tambelan. $S_{0}$ adalah muka laut rata-rata.

\begin{tabular}{cccc}
\hline No & Konstanta & Amplitudo $(\mathrm{m})$ & fase $\left(^{\circ}\right)$ \\
\hline 1 & $\mathrm{~S}_{0}$ & 2,08 & - \\
2 & $\mathrm{M}_{2}$ & 0,09 & 293,25 \\
3 & $\mathrm{~S}_{2}$ & 0,06 & 270,63 \\
4 & $\mathrm{~N}_{2}$ & 0,02 & 320,10 \\
5 & $\mathrm{~K}_{1}$ & 0,25 & 328,48 \\
6 & $\mathrm{O}_{1}$ & 0,19 & 272,83 \\
\hline
\end{tabular}

Tabel 1 menampilkan amplitudo dan fase dari masing-masing konstantan harmonik pasang surut dari hasil pengukuran. Berdasarkan hasil analisis didapatkan nilai elevasi MSL sebesar 2,08 $\mathrm{m}$. Nilai chart datum yang didapat dari hasil perhitungan sebesar 1,32 m dari MSL. Nilai chart datum dengan acuan ISLW dan MSL hasil pengukuran pasut digunakan untuk koreksi terhadap batimetri.

\subsection{Batimetri Perairan Teluk Tambelan}

Kontur batimetri (Gambar 4)
memperlihatkan bahwa di bagian Utara dan Timur berwarna kuning sampai hijau. Di daerah tersebut nilai kedalaman berkisar 2 meter. Selanjutnya, kedalaman 5, 10 dan 15 meter berada di pertengahan teluk yang ditunjukkan dengan kontur berwarna hijau tua. Kedalaman maksimum $>20 \mathrm{~m}$ ditunjukkan dengan kontur yang berwarna biru ke arah laut lepas. Zona pasang surut adalah daerah pantai yang terletak antara pasang yang tinggi dan surut terendah. Daerah ini mewakili peralihan dari kondisi lautan ke kondisi daratan. Pada peta kedalaman ISLW terdapat wilayah dengan zona pasang surut pada kedalaman garis kontur 0 meter.
Kelerengan (slope) dasar perairan dapat diketahui menggunakan metode Wenworth dengan masukan kontur batimetri hasil pengolahan data batimetri (Gambar 4).

Tabel 2. kelerengan dasar perairan dan klasifikasinya

\begin{tabular}{lll}
\hline titik & $\mathrm{S}(\%)$ & Keterangan \\
\hline AA' $^{\prime}$ & 5 & Lereng landai \\
BB' $^{\prime}$ & 5,56 & Lereng landai \\
CC' $^{\prime}$ & 15 & Lereng miring \\
DD' & 5,26 & Lereng landai \\
\hline
\end{tabular}

Penampang 1 pada Gambar 5, dari titik A ke titik A', dapat dikategorikan sebagai landai. Pada penampang $\mathrm{AA}^{\prime}$ kedalaman perairan sebesar 5 meter. Kondisi dasar perairan pada titik $A^{\prime}$ terdapat cekungan dasar perairan yang dibuat sebagai jalur keluar dan masuknya kapal motor nelayan di saat air surut. Pada penampang 2, dari B ke B' dikategorikan lereng landai dengan kedalaman berkisar 10 meter. Pada penampang 3 titik CC' memiliki nilai presentase kelerengan tertinggi dengan kedalaman perairan sebesar 15 meter. Selanjutnya pada gambar titik $\mathrm{C}$ termasuk kategori landai, sedangkan titik $\mathrm{C}^{\prime}$ mengalami kelerengan yang miring. Pada daerah titik C terdapat air, namun memiliki garis di atas. Hal ini dikarenakan terdapat zona intertidal pada daerah tersebut. Pada penampang 4 daerah titik DD' berada di mulut teluk. Titik $\mathrm{D}$ termasuk dalam kategori lereng landai karena berada di laut lepas dan titik D' termasuk dalam perairan dangkal. Pada daerah garis penampang 4 memiliki kedalaman sebesar 20 meter. 


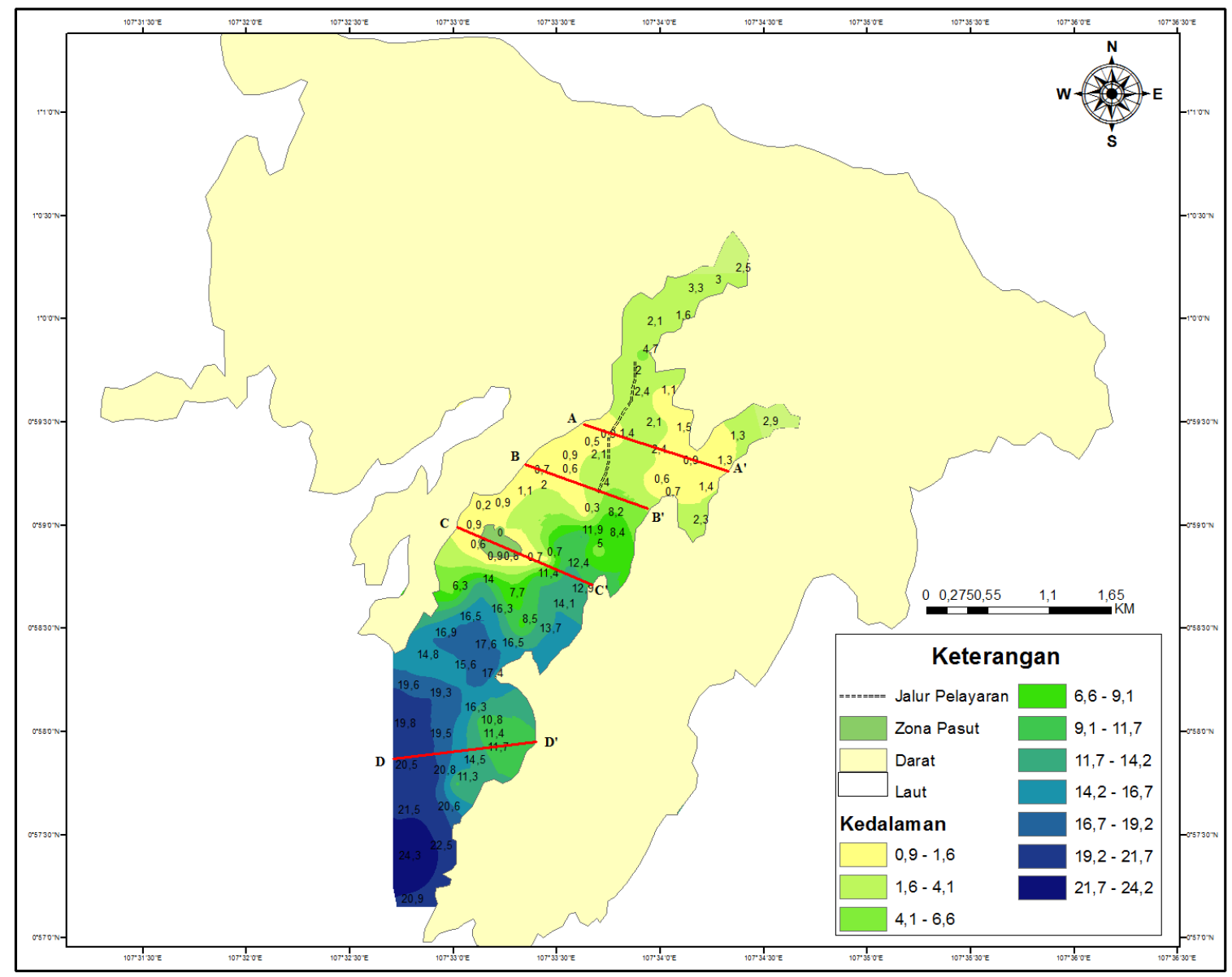

Gambar 4. Kontur Batimetri dan garis penampang melintang perairan
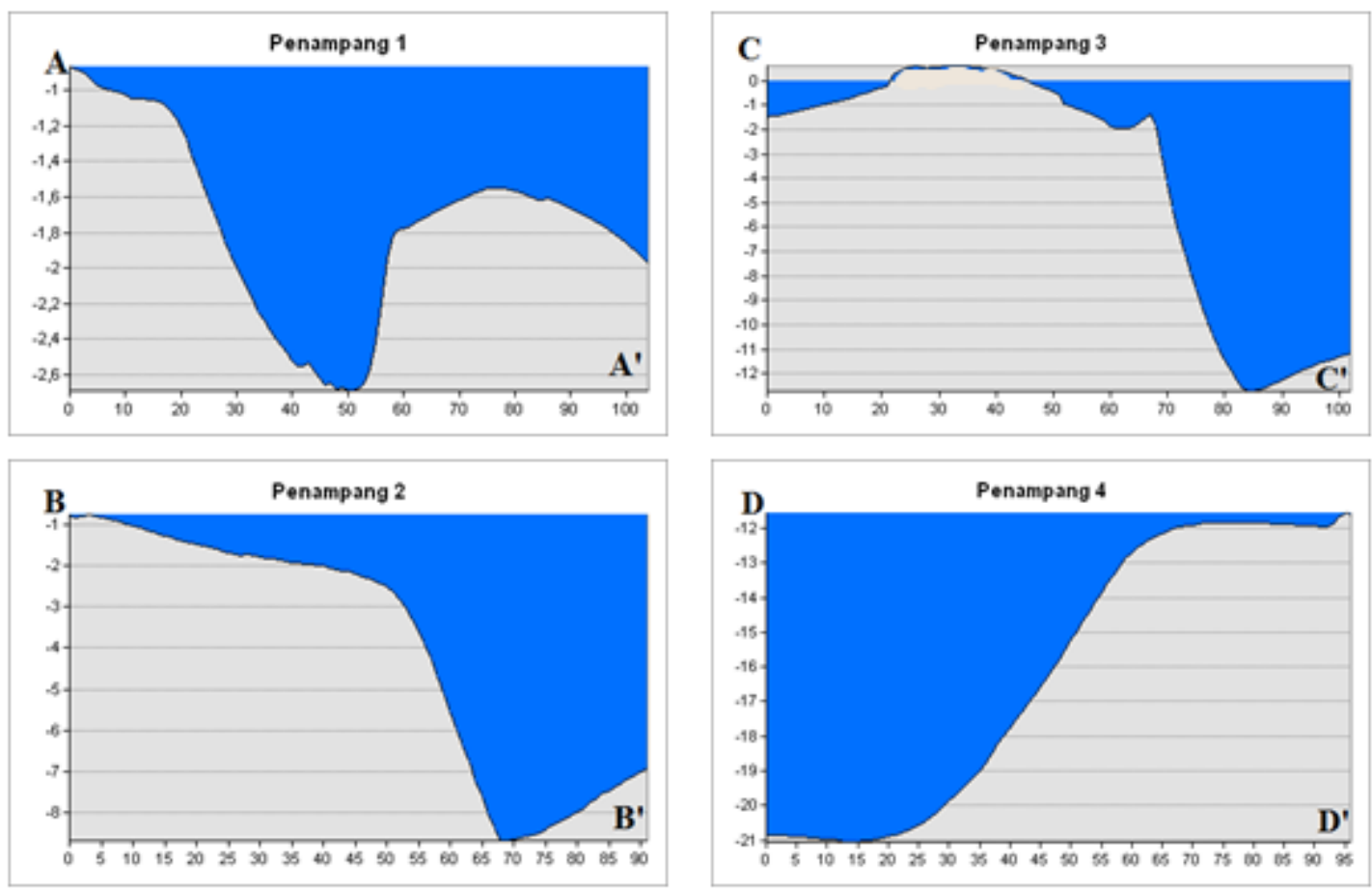

Gambar 5. Penampang melintang kelerengan dasar perairan 


\subsection{Sebaran Spasial Salinitas}

Sebaran salinitas pada lapisan permukaan menunjukkan salinitas tinggi berada di daerah mulut teluk, sedangkan salinitas lebih rendah terletak di tengah teluk. Rendahnya salinitas tersebut dapat disebabkan adanya aliran air tawar yang masuk dari bukit melalui parit-parit yang menuju ke teluk sehingga mengakibatkan terjadinya pencampuran air tawar dan air asin sehingga salinitas pada daerah tersebut menjadi rendah. Pola sebaran salinitas semakin meningkat ke arah laut dikarenakan massa air asin tinggi di laut lepas. Salinitas permukaan pada Gambar 6 daerah dangkal cenderung lebih rendah dikarenakan adanya masukan air tawar, massa air tawar sangat ringan dibandingkan dengan massa air asin. Hal ini menyebabkan, air laut masuk melalui lapisan dasar sedangkan air tawar ke lapisan permukaan. Daerah Utara ujung teluk terlihat pola sebaran salinitas tinggi dari pertengahan teluk. Hal ini karena terjadinya pencampuran massa air yang menyebabkan terbentuknya massa air yang baru.

Pola sebaran salinitas dasar pada Gambar 7 di Perairan Teluk Tambelan menunjukkan nilai salinitas tinggi terletak di mulut teluk dan di ujung teluk bagian Utara, sedangkan salinitas terendah berada di bagian tengah teluk. Nilai salinitas rendah diperkirakan karenadanya air dari aliran bukit, sehingga menyebabkan pencampuran air tawar dan air asin. Sebaran salinitas permukaan sampai dasar di bagian tengah teluk bersalinitas rendah, dikarenakan pada perairan yang dangkal cenderung mempercepat proses pencampuran massa air. Sebaran salinitas semakin meningkat ke arah laut karena air laut mengandung kadar garam yang tinggi. Pada daerah ujung teluk di Utara terdapat sebaran salinitas yang tinggi. Hal ini dipengaruhi arus pasut yang cenderung yang memiliki arah acak, sehingga massa air bersalinitas rendah bercampur dengan massa air bersalinitas tinggi dengan berlangsung lebih cepat.

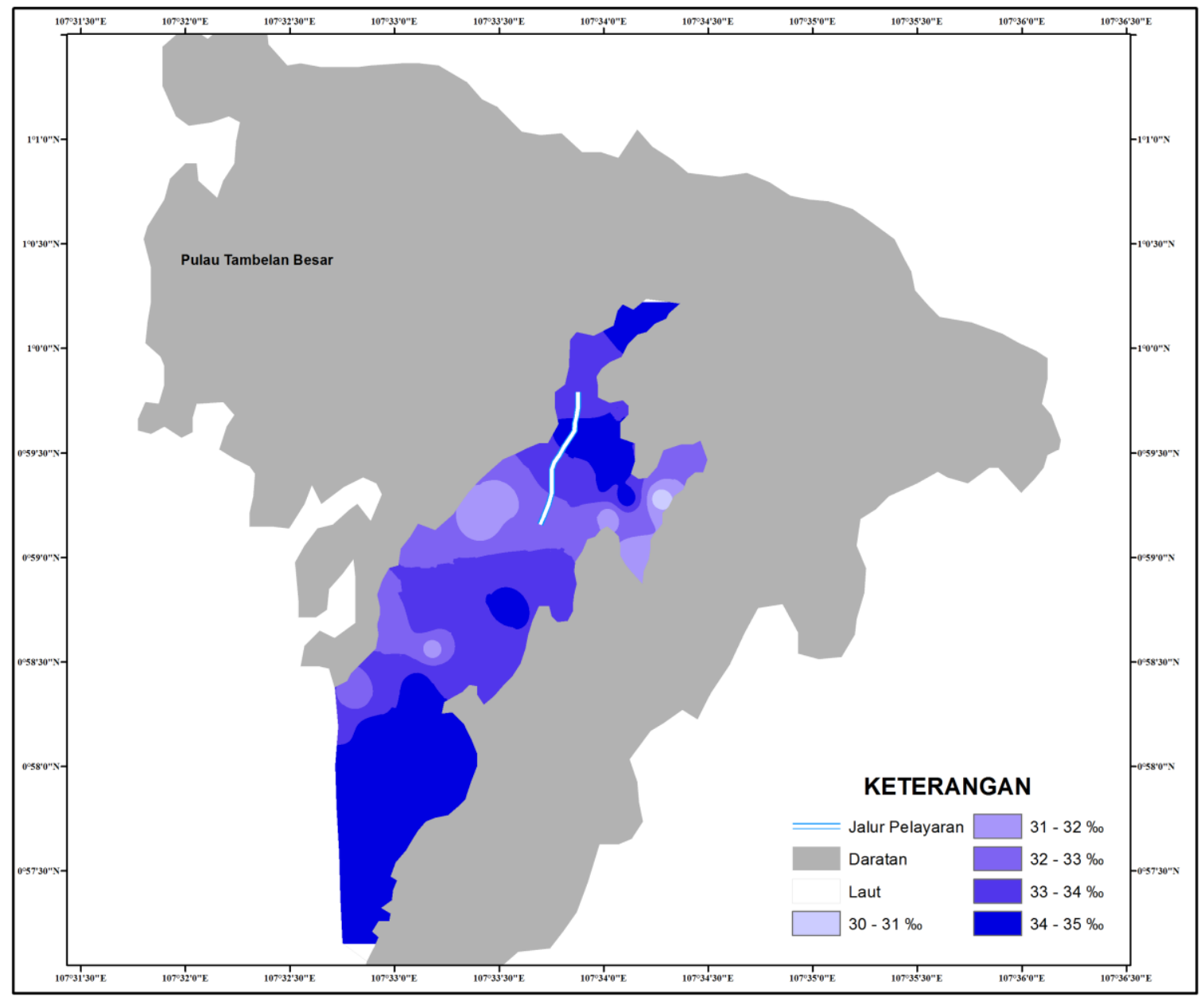

Gambar 6. Sebaran salinitas di bagian permukaan yaitu pada kedalaman $0,2 d$ 


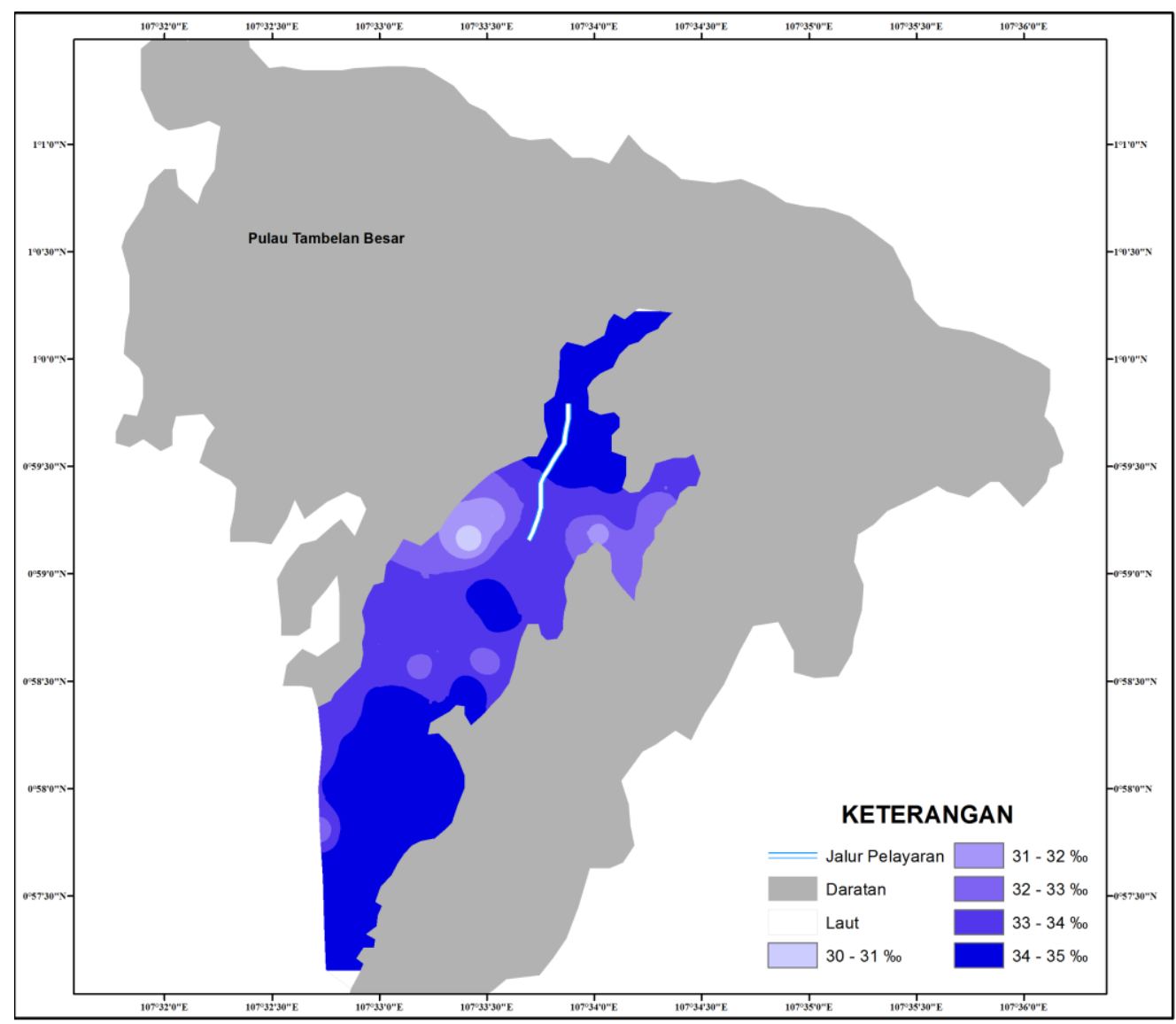

Gambar 7. Sebaran salinitas di bagian dasar yaitu di kedalaman 0,8d

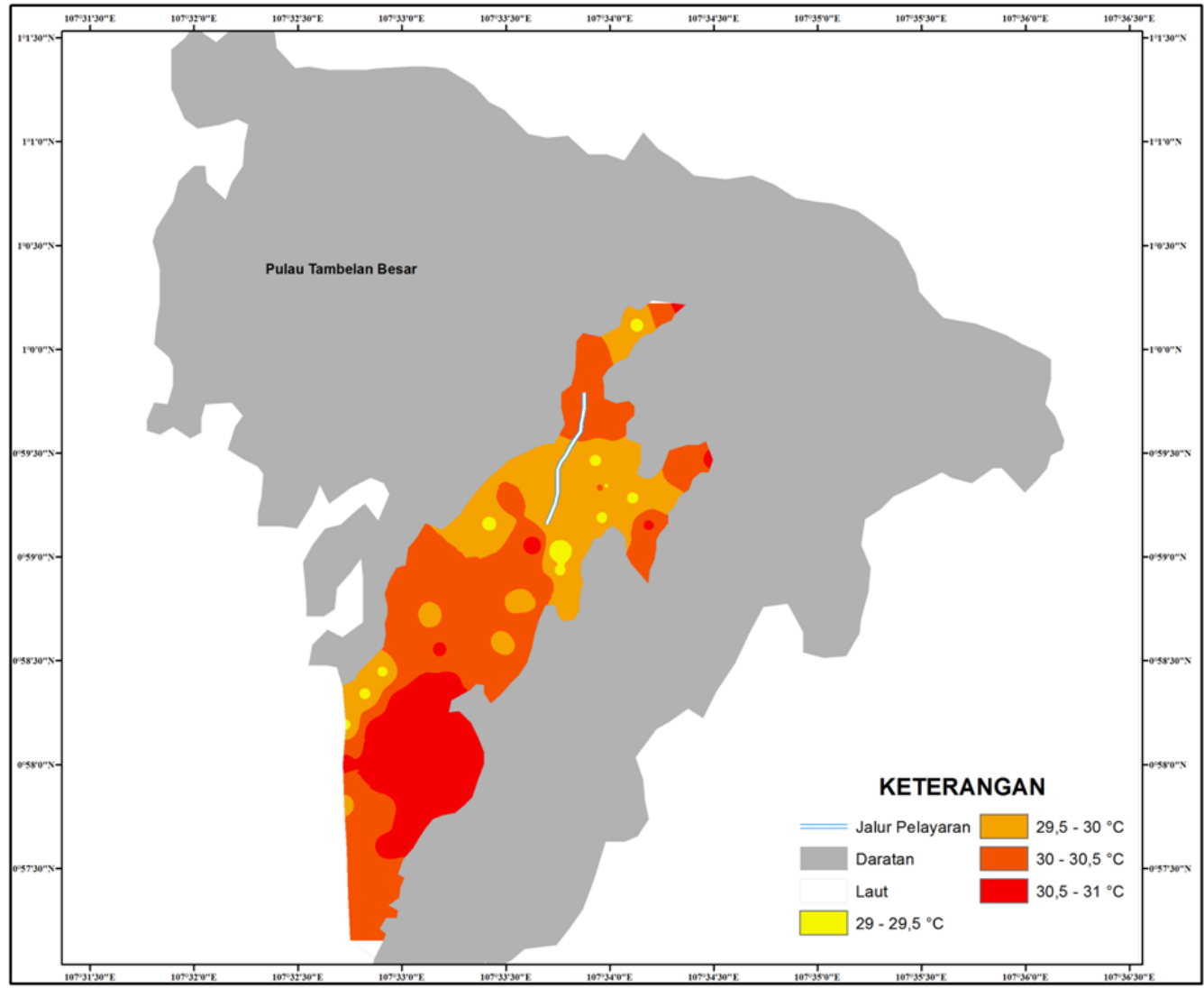

Gambar 8. Sebaran suhu di bagian permukaan yaitu di kedalaman $0,2 d$ 


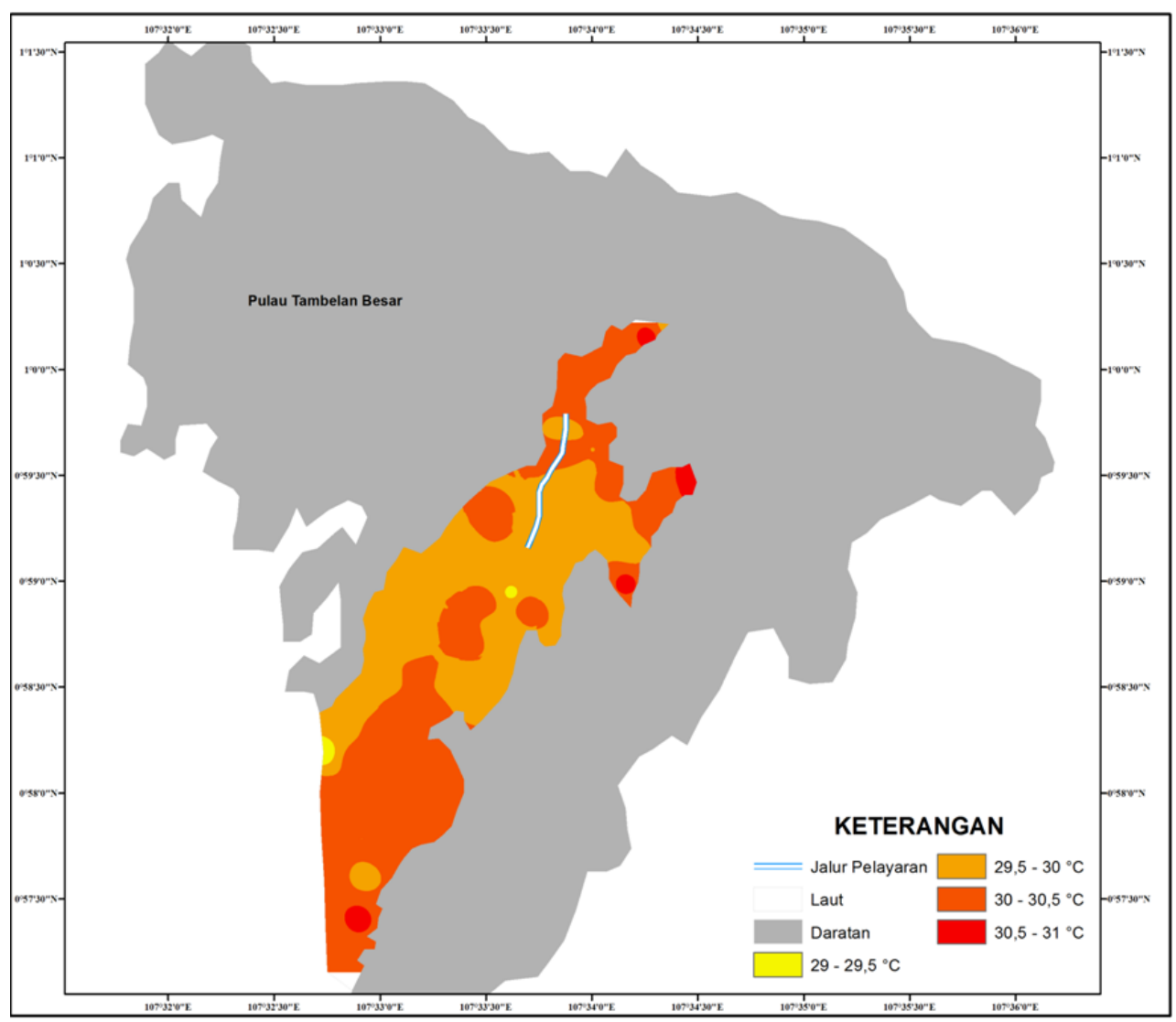

Gambar 9. Sebaran suhu di bagian dasar yaitu di kedalaman 0,8d

\subsection{Sebaran Spasial Suhu}

Sebaran suhu permukaan pada Gambar 8 di bagian tengah teluk memperlihatkan suhu yang lebih rendah dari daerah yang lain disekitarnya. Rendahnya suhu kemungkinan disebabkan oleh proses pencampuran massa air sebagai akibat dari kuatnya arus di daerah yang sempit dan dangkalnya perairan [8]. Adanya masukan air tawar tercampur dengan air asin, sehingga membuat massa air yang baru bersuhu rendah terkumpul di daerah itu. Pengambilan data pada saat pagi juga dapat mempengaruhi rendahnya suhu karena belum optimalnya penyinaran matahari. Daerah ujung teluk Utara, memiliki suhu lebih hangat daripada di bagian tengah teluk. Hal ini kemungkinan adanya arus pasut yang kuat. Suhu lebih hangat ini dipengaruhi massa air tawar yang masuk ke perairan teluk melalui aliran dari bukit yang banyak menuju ke perairan ini.

Sebaran spasial suhu lapisan dasar pada Gambar 9 menunjukkan bahwa suhu tertinggi terletak pada mulut teluk dan ujung teluk di bagian Utara, sedangkan suhu terendah terletak di bagian tengah teluk dan sebelah Barat sejajar dengan pemukiman penduduk. Suhu lebih hangat pada ujung teluk, dipengaruhi oleh gerakan air tawar yang masuk ke perairan teluk. Sebaran suhu terendah terletak di bagian tengah teluk, suhu terendah ini dipengaruhi waktu pengamatan yang dilakukan pagi hari. Perairan dangkal cenderung cepat berubah dikarenakan matahari yang menyinari langsung sampai ke dasar perairan. Arus pasut sangat mempengaruhi suhu, seperti di daerah dekat dengan pantai. Sebaran suhu yang terletak di mulut teluk terlihat memiliki suhu sangat tinggi.

\subsection{Sebaran Spasial Densitas}

Sebaran densitas di Perairan Teluk Tambelan di lapisan permukaan berkisar antara $1019 \mathrm{Kg} / \mathrm{m}^{3}-1021,5 \mathrm{Kg} / \mathrm{m}^{3}$ dengan rata-rata nilai densitas sebesar $1020,64 \mathrm{Kg} / \mathrm{m}^{3}$. Untuk melihat pola sebaran densitas permukaan dapat dilihat pada Gambar 10. Pola sebaran densitas dipermukaan menunjukkan nilai yang dominan lebih rendah dari densitas lapisan dasar. Densitas sangat dipengaruhi oleh suhu, jika suhu diperairan tinggi maka densitas air menjadi rendah. Daerah pertengahan teluk memiliki nilai densitas yang sangat rendah. Hal ini dikarenakan terjadinya pencampuran massa air tawar dan air asin, sehingga mengakibatkan densitas pada kawasan perairan dangkal menjadi rendah. Sebaran densitas permukaan yang berwarna merah merupakan nilai densitas tertinggi yang dipengaruhi oleh suhu yang rendah dan salinitas tinggi. Pada daerah ujung teluk di Utara terjadi 


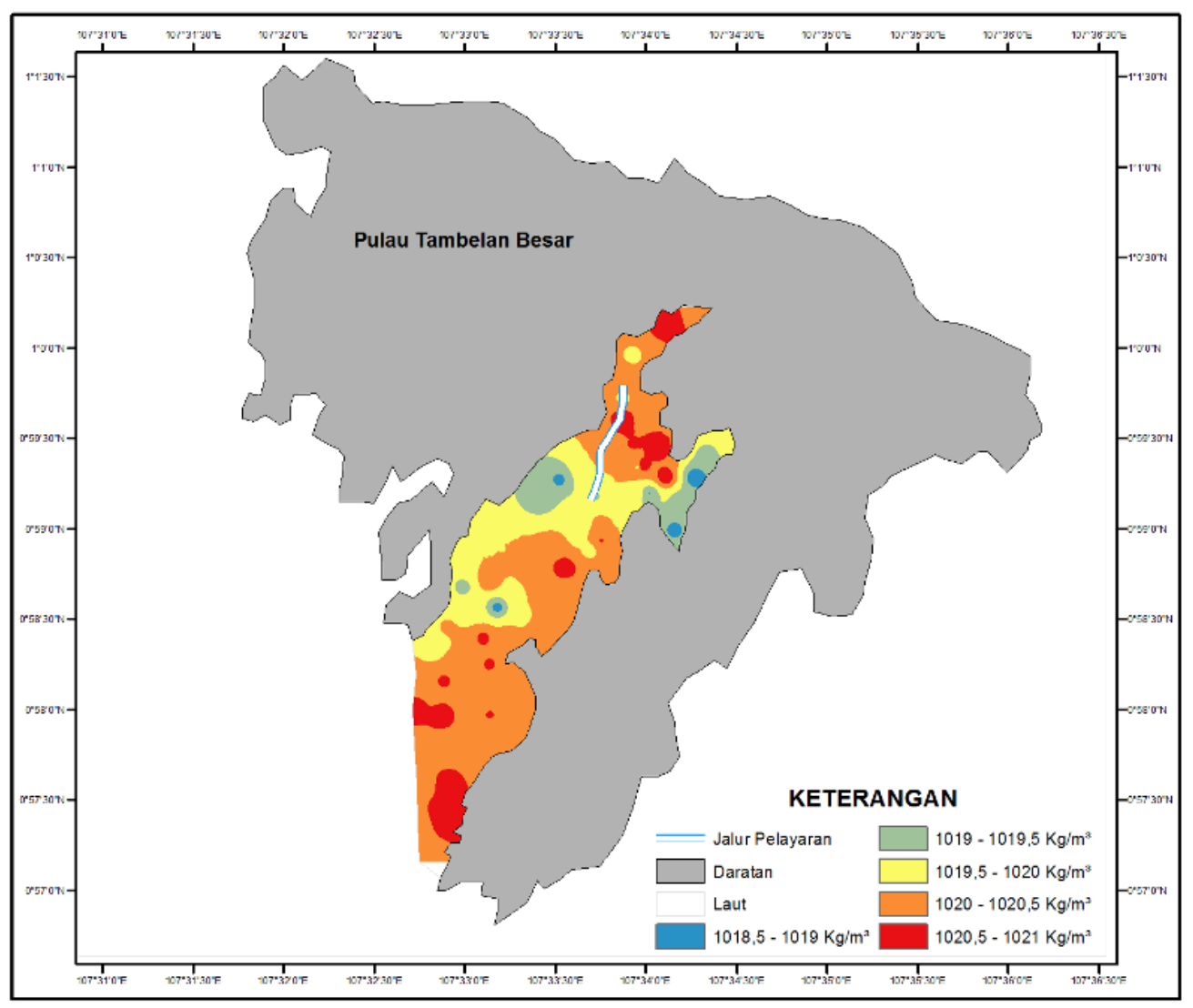

Gambar 10. Sebaran densitas di bagian permukaan yaitu di kedalaman $0,2 d$

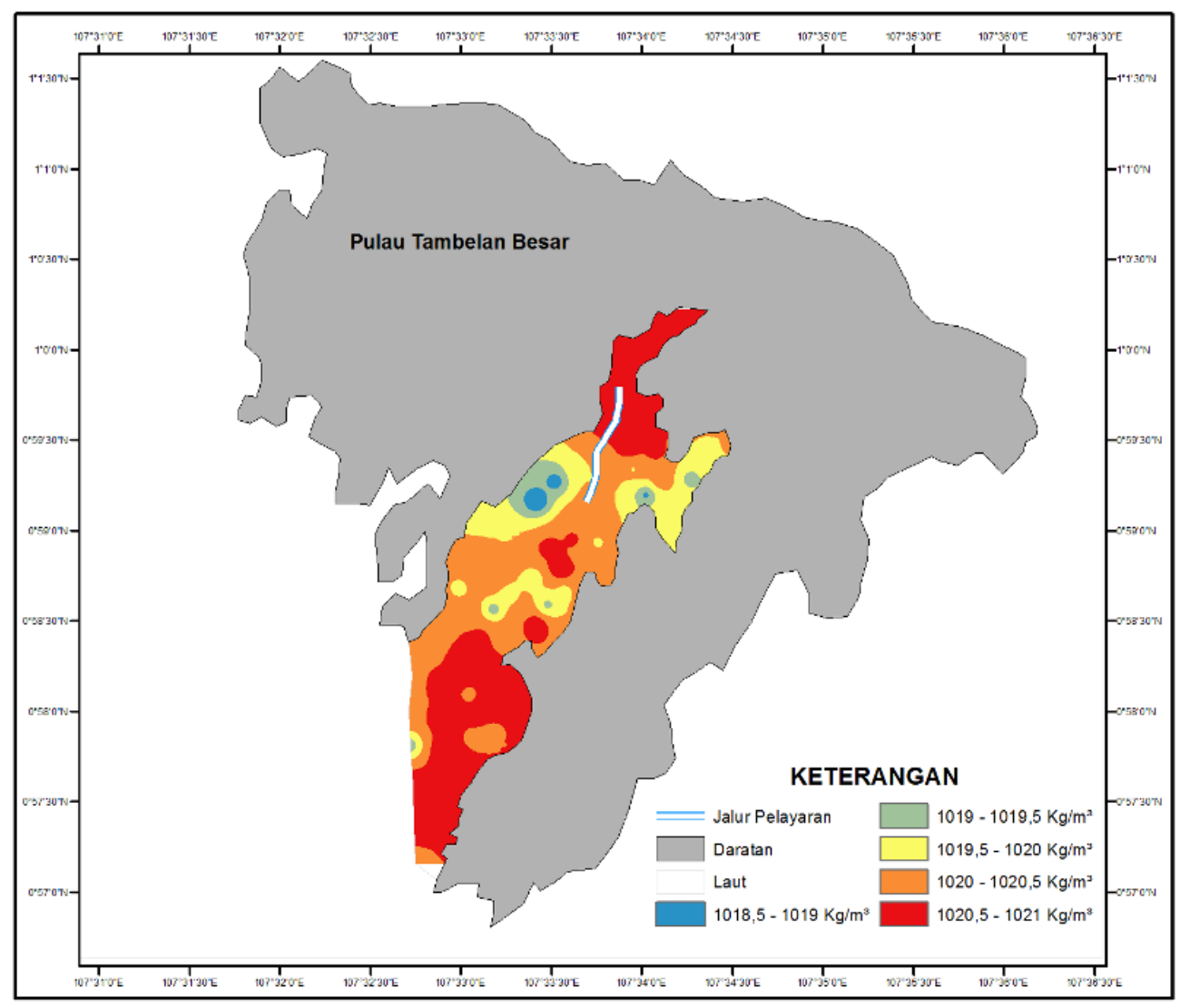

Gambar 11. sebaran densitas di bagian dasar yaitu di kedalaman $0,8 d$ 
peningkatan densitas, hal ini dipengaruhi oleh nilai salinitas perairan. Semakin jauh dengan pinggiran teluk, nilai densitas juga cenderung naik. Hal ini mengindikasikan adanya massa air dengan suhu dan salinitas tinggi, sehingga densitas akan menjadi tinggi. Densitas perairan dekat pinggiran teluk lebih rendah karena kedalaman yang dangkal dan adanya aliran air tawar yang masuk. Pada daerah mulut teluk, perairan teluk berhubungan langsung dengan air laut. Daerah ini dapat dipengaruhi oleh nilai salinitas dan arus dari laut. Massa air laut merupakan massa air yang lebih berat sehingga kemungkinan besar daerah mulut teluk merupakan lokasi tenggelamnya massa air yang berdensitas tinggi.

Densitas lapisan dasar pada Gambar 11 memiliki nilai berkisar $1019 \mathrm{Kg} / \mathrm{m}^{3}$ - 1021,5 $\mathrm{Kg} / \mathrm{m}^{3}$ dengan rata-rata $1021,05 \mathrm{Kg} / \mathrm{m}^{3}$. Pola densitas lapisan dasar dilihat pada Gambar 10 dengan nilai lebih bervariasi dari daerah Utara ke mulut teluk. Penyebaran densitas disebabkan karena adanya perbedaan suhu dan salinitas [9]. Pola sebaran densitas lapisan dasar pada menunjukkan semakin dalam kedalamannya semakin tinggi nilai densitasnya. Mulut teluk memiliki suhu rendah dan salinitas tinggi, sehingga densitas air daerah ini menjadi cukup tinggi yang dipengaruhi oleh salinitas. Daerah mulut teluk merupakan perairan teluk yang berhubungan langsung dengan air laut, sehingga densitas dasar perairan menjadi tinggi.

\section{Kesimpulan}

Berdasarkan pada penelitian yang telah dilakukan maka diperoleh kesimpulan yaitu:

1. Kedalaman di Teluk Tambelan berkisar antara 0,2 - 24,3 meter.

2. Salinitas di Teluk Tambelan pada lapisan permukaan $(0,2 d)$ dan lapisan dasar $(0,8 d)$ berkisar antara $30-35 \%$.

3. Suhu di Teluk Tambelan pada lapisan permukaan $(0,2 d)$ berkisar antara 28,5 - 31 ${ }^{\circ} \mathrm{C}$ sedangkan pada lapisan dasar $(0,8 d)$ suhu berkisar antara $28-31^{\circ} \mathrm{C}$.
4. Densitas pada lapisan permukaan $(0,2 d)$ berkisar antara $1019 \mathrm{Kg} / \mathrm{m}^{3}-1021,5 \mathrm{Kg} / \mathrm{m}^{3}$ sedangkan pada lapisan dasar $(0,8 d)$ densitas berkisar antara $1019 \mathrm{Kg} / \mathrm{m}^{3}$ $1021,5 \mathrm{Kg} / \mathrm{m}^{3}$.

\section{Daftar Pustaka}

[1] Badan Pusat Statistik Kabupaten Bintan. 2017. Statistik Daerah Kabupaten Bintan tahun 2017, Kabupaten Bintan : Badan Pusat Statistik

[2] Ulumuddin, Y., 2012."Species Diversity of Rhizophora In Tambelan Islands, Natuna Sea, Indonesia".jurnal Biodiversitas, vol. 13 no. 4 hal. 172-177

[3] Syaifuddin., 2010. "Sifat Fisik Oseanografi Perairan Kepulauan Tambelan dan Sekitarnya, Propinsi Kepulauan Riau".Jurnal Perikanan dan Kelautan, vol. 15 no. 2 hal. 173-184

[4] Sucilestari, R., Muliati, Y., dan Madrapriya, F., 2017. Desain Pelabuhan Penyebrangan di Tambelan, Provinsi Kepulauan Riau. Reka Rencana, 3(2):1-13.

[5] Rinaldy, Y,N., Nugraha, A,L., Subiyanto, S., 2014. "Analisis pengukuran batimetri dan pasang surut untuk menentukan kedalaman kolam pelabuhan". E-Jurnal Geodesi UNDIP, 3 (4):25-36

[6] Arifianti, Y., 2011. "Potensi Longsor Dasar Laut Di Perairan Maumere". Bulletin Vulkanologi dan Bencana Geologi, 6 (1): 5362

[7] Fofonoff, N.P., Millard Jr, R.C., 1983. "Algorithms for computation of fundamental properties of seawater". UNESCO Tech. Pap. in Mar. Sci. No. 44. hlm 25- 28.

[8] Lindawati, Jumarang, M,I., dan Kushadiwijayanto, A.A., 2018, "Karakteristik Perambatan Gelombang Pasang Surut di Estuari Kapuas Kecil”, J. Laut Khatulistiwa, 1(3):61-66.

[9] Hutabarat, Sahala, dan Evans, S.H., 2008. Pengantar Oseanografi, UI-Press, Jakarta 


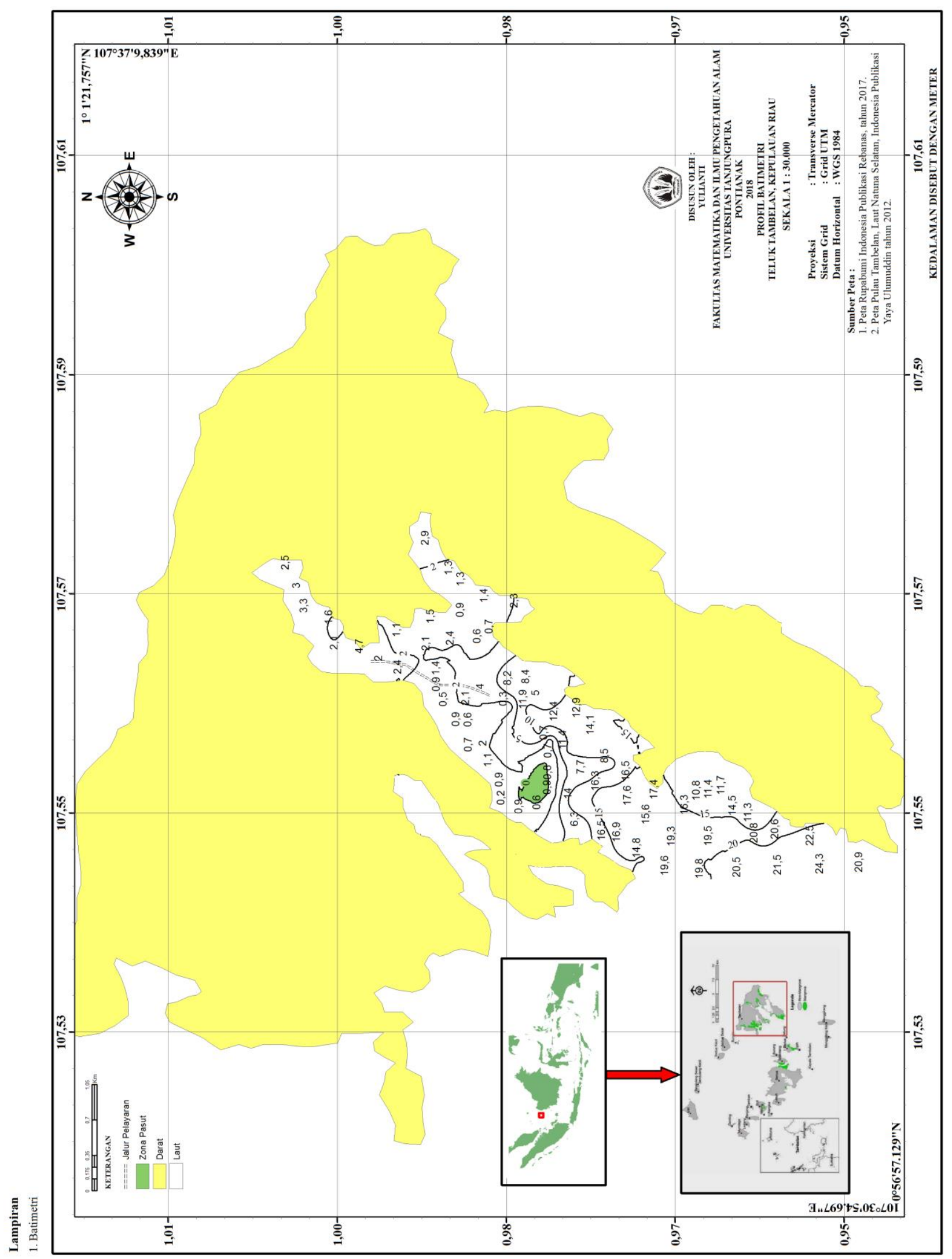

